\title{
Dysregulation of the expression and secretion of inflammation-related adipokines by hypoxia in human adipocytes
}

\author{
Bohan Wang • I. Stuart Wood • Paul Trayhurn
}

Received: 6 March 2007 /Revised: 19 April 2007 / Accepted: 23 May 2007 / Published online: 3 July 2007

(C) Springer-Verlag 2007

\begin{abstract}
The effect of hypoxia, induced by incubation under low (1\%) oxygen tension or by exposure to $\mathrm{CoCl}_{2}$, on the expression and secretion of inflammation-related adipokines was examined in human adipocytes. Hypoxia led to a rapid and substantial increase (greater than sevenfold by $4 \mathrm{~h}$ of exposure to $1 \% \mathrm{O}_{2}$ ) in the hypoxiasensitive transcription factor, HIF- $1 \alpha$, in human adipocytes. This was accompanied by a major increase (up to 14 -fold) in GLUT1 transporter mRNA level. Hypoxia $\left(1 \% \mathrm{O}_{2}\right.$ or $\mathrm{CoCl}_{2}$ ) led to a reduction (up to threefold over $24 \mathrm{~h}$ ) in adiponectin and haptoglobin mRNA levels; adiponectin secretion also decreased. No changes were observed in $\mathrm{TNF} \alpha$ expression. In contrast, hypoxia resulted in substantial increases in FIAF/angiopoietin-like protein 4, IL-6, leptin, MIF, PAI-1 and vascular endothelial growth factor (VEGF) mRNA levels. The largest increases were with FIAF (maximum 210-fold), leptin (maximum 29-fold) and VEGF (maximum 23-fold); these were reversed on return to normoxia. The secretion of IL-6, leptin, MIF and VEGF from the adipocytes was also stimulated by exposure to $1 \%$ $\mathrm{O}_{2}$. These results demonstrate that hypoxia induces extensive changes in human adipocytes in the expression and release of inflammation-related adipokines. Hypoxia may underlie the development of the inflammatory response in adipocytes, leading to obesity-associated diseases.
\end{abstract}

Keywords Adipokines - Adipose tissue · Hypoxia . Inflammation $\cdot$ Obesity $\cdot$ Metabolic syndrome

B. Wang $\cdot$ I. S. Wood $\cdot$ P. Trayhurn $(\bowtie)$

Obesity Biology Unit (Liverpool Centre for Nutritional Genomics and Liverpool Obesity Research Network),

School of Clinical Sciences, University Clinical Departments,

University of Liverpool,

Liverpool L69 3GA, UK

e-mail: p.trayhurn@liverpool.ac.uk
Abbreviations
FIAF fasting-induced adipose factor
HIF- $1 \alpha$ hypoxia inducible factor $1 \alpha$
IL-6 interleukin-6
MCP-1 monocyte chemoattractant protein-1
MIF monocyte migration inhibitory factor
PAI-1 plasminogen activator inhibitor-1
POLR2A RNA II polypeptide A
TNF $\alpha$ tumour necrosis factor- $\alpha$
VEGF vascular endothelial growth factor

\section{Introduction}

White adipose tissue has traditionally been considered as primarily a vehicle for the storage of fuel in the form of triacylglycerols, but several other functions are now recognised for the tissue. In particular, adipose tissue is a major endocrine organ secreting several key hormones, notably leptin and adiponectin [11, 26, 29, 37, 38]. These hormones are part of the large group of protein signals and factors secreted by adipocytes, termed adipokines, many of which are linked to immunity and the inflammatory response [14, 26, 29, 38]. These encompass major cytokines and chemokines, including $\mathrm{TNF} \alpha$, IL-1 $\beta$, IL-6, IL-10, MCP-1 and MIF [11, 26, 38].

Obesity, which is characterised by a major expansion in adipose tissue mass, is associated with a state of chronic mild inflammation, there being increased circulating levels of inflammatory markers such as C-reactive protein, IL-6, IL-18, haptoglobin, MIF and PAI-1 [11, 14, 26, 38]. The production of a number adipokines increases during the expansion of adipose tissue mass in the obese (for example, leptin, MIF, TNF $\alpha$ and PAI-1), with the result that there is an inflammatory state within the tissue [11, 14, 26, 38]. An 
exception is adiponectin, which has an anti-inflammatory action $[25,49]$. Inflammation in WAT is considered to be causal in the development of type 2 diabetes and the metabolic syndrome linked to obesity [11, 14, 26, 29]. There has, however, been little focus on why the rise in adipose tissue mass in the obese should lead to the increased production of inflammatory adipokines. One possibility, which we have recently suggested, is that it is a response to relative hypoxia in clusters of adipocytes distant from the vasculature, inflammation serving to increase blood flow and stimulate angiogenesis [38, 39].

Hypoxia, which occurs, for example, in solid tumours and during wound healing, induces a series of adaptive responses by cells, and a key role in the transmission of the hypoxic response is played by the hypoxia-inducible transcription factors, particularly hypoxia-inducible factor1 (HIF-1) [6, 13, 32, 33, 44]. HIF-1 is composed of two subunits, HIF-1 $\beta$, which is constitutively expressed, and HIF- $1 \alpha$, which is recruited in response to low $\mathrm{O}_{2}$ tension to yield the functional transcription factor $[6,32,44]$. HIF- $1 \alpha$ is present in murine clonal adipocytes, and hypoxia has been shown to induce an increase in the expression of leptin and vascular endothelial growth factor (VEGF) in these cells [21]. Recently, hypoxia has also been reported to induce the production of PAI-1 and to inhibit the synthesis of adiponectin by 3T3-L1 adipocytes [4]; it is also reported to induce the expression of visfatin in these cells [31]. HIF$1 \alpha$ has been identified in human adipose tissue and is reported to be increased in obesity [3]. However, the extent to which human adipocytes respond to hypoxia and which genes are hypoxia-sensitive are unknown.

In the present study, we have examined the effects of hypoxia on the expression and secretion of key adipokines linked to inflammation in human adipocytes differentiated from fibroblastic preadipocytes in culture. The results demonstrate that hypoxia, whether through low $\mathrm{O}_{2}$ tension or induced chemically by $\mathrm{CoCl}_{2}$, leads to a marked recruitment of HIF- $1 \alpha$ in human adipocytes and that expression of the GLUT1 facilitative glucose transporter in adipocytes is hypoxia-sensitive. Importantly, the expression and secretion of several adipokines, including FIAF/ angiopoietin-like protein 4, IL-6, leptin, MIF and VEGF, is stimulated by hypoxia in human adipocytes, while adiponectin and haptoglobin are inhibited.

\section{Materials and methods}

Human adipocyte culture

Human subcutaneous preadipocytes, derived from adipose tissue pooled from seven female subjects, were obtained (together with culture media) from Zen-Bio (USA). The patients had a mean body mass index of 25 (range 22.528.2) and average age of 41 years (range 27-51 years).

Cells were trypsinized from a $75-\mathrm{cm}^{2}$ flask and plated at a density of $40,000 / \mathrm{cm}^{2}$ in a $24-w e l l$ plate and maintained in preadipocyte medium containing Dulbecco's modified Eagle's medium (DMEM)/Ham's F12 $(1: 1, v / v), 10 \%$ fetal calf serum (FCS), $15 \mathrm{mM}$ HEPES, $100 \mathrm{U} / \mathrm{ml}$ penicillin, $100 \mu \mathrm{g} / \mathrm{ml}$ streptomycin and $0.25 \mu \mathrm{g} / \mathrm{ml}$ amphotericin B at $37^{\circ} \mathrm{C}$ in a humidified atmosphere of $95 \%$ air $/ 5 \% \mathrm{CO}_{2}$. Cells were induced at confluence by incubation in differentiation medium composed of adipose medium (AM) supplemented with $0.25 \mathrm{mM}$ isobutyl methylxanthine and $10 \mu \mathrm{M}$ of a PPAR $\gamma$ agonist for 4 days. The cells were then cultured with AM containing DMEM/Ham's F-12 $(1: 1, v / v), 3 \%$ FCS, $1 \mu \mathrm{M}$ dexamethasone, $100 \mathrm{U} / \mathrm{ml}$ penicillin, $100 \mu \mathrm{g} / \mathrm{ml}$ streptomycin and $0.25 \mu \mathrm{g} / \mathrm{ml}$ amphotericin B. The medium was changed every 3 days.

Fully differentiated cells at day 15 post-induction were treated with $\mathrm{CoCl}_{2}$ or exposed to $1 \% \mathrm{O}_{2}$ for up to $24 \mathrm{~h}$. For $\mathrm{CoCl}_{2}$ treatment, wells incubated without $\mathrm{CoCl}_{2}$ were used as controls; $75-200 \mu \mathrm{M} \mathrm{CoCl}_{2}$ was used in initial experiments, and $100 \mu \mathrm{M} \mathrm{CoCl}_{2}$ was employed in a time course study. For exposure to hypoxia, the cells were transferred to a MIC-101 modular incubator chamber (Billups-Rosenberg, USA), which was flushed with $1 \% \mathrm{O}_{2}, 94 \% \mathrm{~N}_{2}$ and $5 \%$ $\mathrm{CO}_{2}$, and sealed and placed at $37^{\circ} \mathrm{C}$ for up to $24 \mathrm{~h}$ as indicated. The control cells were cultured in a standard incubator $\left(21 \% \mathrm{O}_{2}\right.$ and $\left.5 \% \mathrm{CO}_{2}\right)$. The cells were harvested in $700 \mu \mathrm{l}$ of Trizol (Invitrogen, UK) or $150 \mu \mathrm{l}$ of lysis buffer per well at the stated time points. Media were collected and centrifuged at $1,000 \mathrm{rpm}$ for $10 \mathrm{~min}$ to remove cell debris and the supernatant stored at $-20^{\circ} \mathrm{C}$ until required for analysis. All incubations at each time point were performed in replicates of up to six wells.

\section{RNA extraction and cDNA synthesis}

Total RNA was isolated from cells using Trizol, and $1 \mu \mathrm{g}$ of RNA was treated with DNase I (Invitrogen) according to the manufacturer's instructions. RNA concentration was quantified from the absorbance at $260 \mathrm{~nm}$; all samples had a 260/280 nm absorbance ratio of 1.7-1.9.

One microgram of DNase I-treated RNA was reversetranscribed using a Reverse-i $\mathrm{T}^{\mathrm{TM}} 1^{\mathrm{ST}}$ strand synthesis kit (Abgene, UK) in the presence of anchored oligo dT in a total volume of $20 \mu$ l.

\section{Real-time PCR}

Quantitative real-time polymerase chain reactions (PCRs) were carried out in a final volume of $12.5 \mu \mathrm{l}$ consisting of 12.5-50 ng of reverse-transcribed cDNA mixed with optimal concentrations of primers and probe and $\mathrm{qPCR}^{\mathrm{TM}}$ 
core kit (Eurogentec, UK) in 96-well plates on a Mx3005P detector (Stratagene, USA).

The primer and probe sets were designed using Primer Express software (Applied Biosystems) and synthesized commercially; the primers and TaqMan probes were from Eurogentec. TaqMan probes were labelled with a reporter fluorescent dye (FAM: 6-carboxyfluorescein) at the 5'-end and a fluorescent dye quencher (TAMRA: 6-carboxytetramethyl-rhodamine) at the 3 '-end. The sequence and optimal concentrations of primers and probes, together with the size of products, are as detailed previously [41, 42], with the exception of GLUT1, FIAF, HIF-1 $\alpha$, MIF and POLR2A which were as follows.

GLUT1 (93 bp): 5'-ATACTCATGACCATCGCGCTAG-3' (forward), 5'-AAAGAAGGCCACAAAGCCAAAG-3' (reverse) and $5^{\prime}$-FAM-TGGAGCAGCTACCCTGGATGTCC TATCTGA-TAMRA-3' (probe);

FIAF (117 bp): 5'-GATGGCTCAGTGGACTTCAACC-3' (forward), 5'-CCCGTGATGCTATGCACCTTC-3' (reverse) and 5'-FAM-CCAGACCCAGCCAGAACTCGCCGTTAMRA-3' (probe);

HIF-1 $\alpha$ (75 bp): 5'-TCCAGTTACGTTCCTTCGATCA-3' (forward), 5'-TTTGAGGACTTGCGCTTTCA-3' (reverse) and 5'-FAM-CACCATTAGAAAGCAGTTCCGCAAGCCTAMRA-3' (probe);

MIF (74 bp): 5'-AGCCCGGACAGGGTCTACA-3' (forward), 5'-GCGAAGGTGGAGTTGTTCCA-3' (reverse) and 5'-FAM-CTATTACGACATGAACGCGGCCAATGTTAMRA-3' (probe);

POLR2A (81 bp): 5'-ATGGAGATCCCCACCAA TATCC-3' (forward), 5'-CATGGGACTGGGTGCTGAAC-3' (reverse) and 5'-FAM-TGCTGGACCCACCGGCATGTTC TAMRA-3' (probe).

Typically, the amplification started with $2 \mathrm{~min}$ at $50^{\circ} \mathrm{C}$, $10 \mathrm{~min}$ at $95^{\circ} \mathrm{C}$ and then 40 cycles of the following: $15 \mathrm{~s}$ at $95^{\circ} \mathrm{C}$ and $1 \mathrm{~min}$ at $60^{\circ} \mathrm{C}$.

Human POLR2A was used as an endogenous reference. This housekeeping gene was selected based on comparison with $\beta$-actin, where POLR2A demonstrated no significant changes in expression when exposed to $\mathrm{CoCl}_{2}$ and $1 \% \mathrm{O}_{2}$ (data not shown). Relative quantitation values were expressed using the $2^{-\Delta \Delta C t}$ method (see user bulletin no. 2, ABI Prism 7700, pp 11-15, Applied Biosystems), as fold changes in the target gene normalised to the reference gene (POLR2A) and related to the expression of the untreated controls. The PCR efficiency in all runs was close to $100 \%$, and all samples were analysed in at least duplicate.

\section{Measurement of HIF-1 $\alpha$ and adipokines by ELISA}

Total HIF-1 $\alpha$ in cell lysates was measured with an enzymelinked immunosorbent assay (ELISA) kit (R\&D Systems, UK) according to the manufacturer's protocol. Cells were solubilised in lysis buffer consisting of $50 \mathrm{mM}$ Tris (pH 7.4), $300 \mathrm{mM} \mathrm{NaCl}, 10 \%(w / v)$ glycerol, $3 \mathrm{mM}$ ethylenediaminetetraacetic acid, $1 \mathrm{mM} \mathrm{MgCl} 2,20 \mathrm{mM} \beta$-glycerophosphosphate, $25 \mathrm{mM} \mathrm{NaF}, 1 \%$ Triton X-100, $25 \mu \mathrm{g} / \mathrm{ml}$ leupeptin, $25 \mu \mathrm{g} / \mathrm{ml}$ pepstatin and $3 \mu \mathrm{g} / \mathrm{ml}$ aprotinin. Before measuring HIF- $1 \alpha$ by ELISA, the total protein content of the lysates was determined by the BCA protein assay reagent (Sigma, UK).

Adiponectin, IL-6, leptin, MIF and VEGF were measured in cell culture media using commercial ELISA kits (R\&D Systems). The assays were conducted in 96-well microplates according to the manufacturer's instructions.

Measurement of HIF- $1 \alpha$ by Western blotting

Samples were prepared as described above for the HIF- $1 \alpha$ ELISA assay. Fifteen micrograms of protein were separated by sodium dodecyl sulfate-polyacrylamide gel electrophoresis and then transferred to a nitrocellulose membrane. The membranes were blocked and probed with polyclonal goat anti-human HIF-1 $\alpha$ (R\&D Systems) or mouse monoclonal anti- $\alpha$-tubulin (Sigma, UK) as the primary antibody, then subjected to HRP-conjugated anti-goat IgG (R\&D systems) or anti-mouse IgG (Santa Cruz Biotechnology) as the secondary antibody. Specific proteins were visualised with the enhanced chemiluminescence reagent (Amersham, UK).

\section{Statistical analysis}

The results are expressed as mean values \pm SE. Differences between groups were analysed by unpaired two-tailed Student's $t$ tests.

\section{Results}

HIF-1 $\alpha$ expression during differentiation of human adipocytes

We first investigated whether human white adipocytes express the HIF- $1 \alpha$ gene and synthesize the encoded protein when differentiated in culture. Quantitative changes in HIF- $1 \alpha$ gene expression after the induction of adipocyte differentiation were analysed by real-time PCR. Although the HIF- $1 \alpha$ gene was expressed both before and after differentiation, there was a marked decrease in HIF- $1 \alpha$ mRNA level after differentiation was induced (Fig. 1a): By day 2 , the mRNA level fell to $<25 \%$ of that seen at day 0 and remained low. The expression of a classical adipokineleptin - was determined as a reference gene. As expected, leptin mRNA was differentiation-dependent and detectable only at day 2 after the induction of differentiation, increasing progressively thereafter (Fig. 1b). 
a

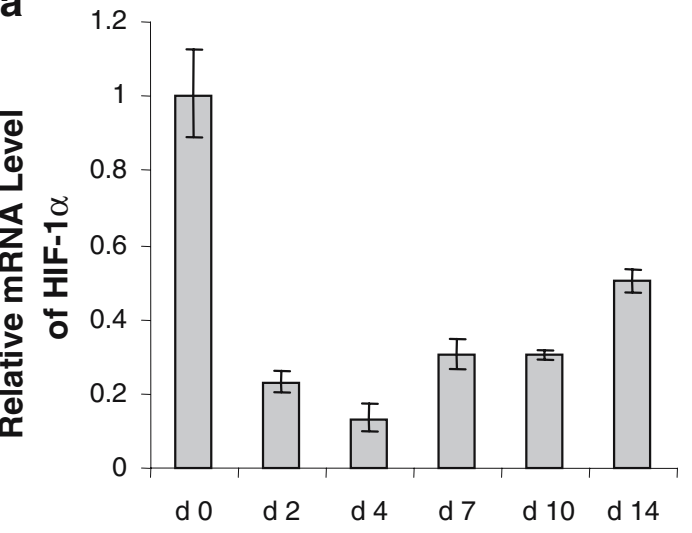

days post-induction
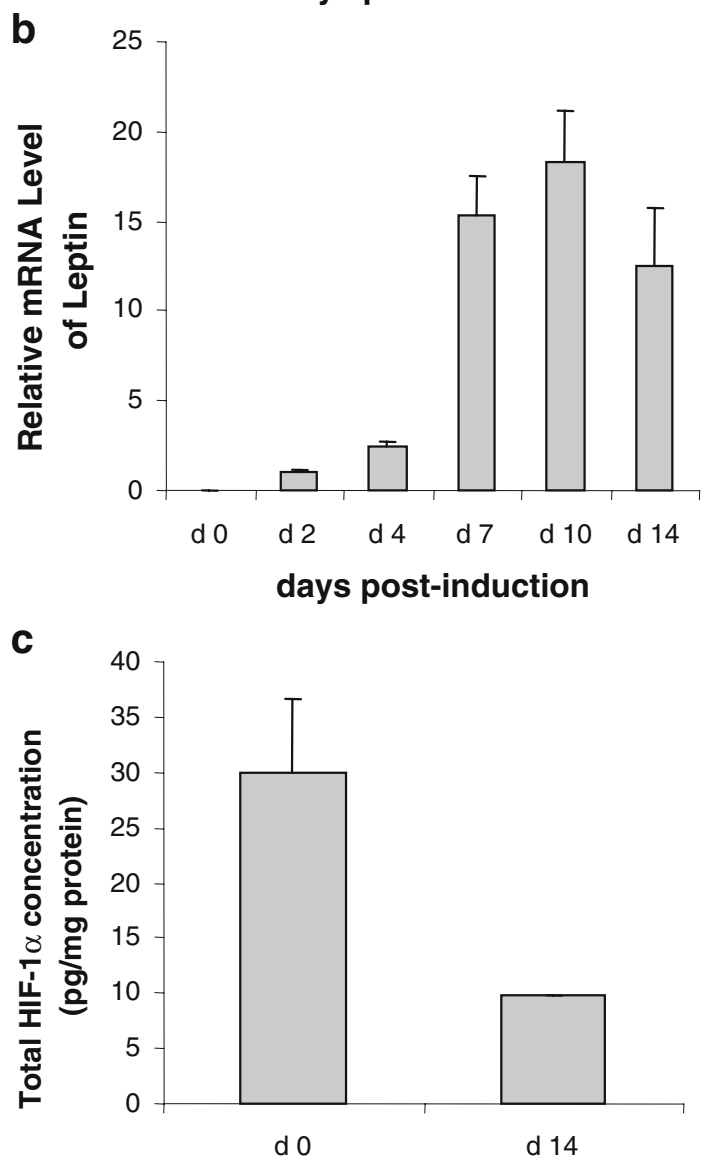

days post-induction

Fig. 1 Time course of quantitative changes in HIF-1 $\alpha$ mRNA level (a), leptin mRNA level (b) and HIF-1 $\alpha$ protein (c) during the differentiation and development of human adipocytes. Confluent human preadipocytes (day 0 ) were differentiated and cultured for up to 14 days. Relative mRNA levels were normalised to human POLR2A at day 0 (or day 2 when no signal was evident at day 0 ). Total protein concentration of HIF-1 $\alpha$ in cell lysates was measured by ELISA. Results are means \pm SE $(n=3)$
HIF- $1 \alpha$ protein expression was examined at day 0 and day 14 using a specific ELISA and was detected at both time points. In parallel with the mRNA level, HIF- $1 \alpha$ protein was substantially higher in preadipocytes than in adipocytes (Fig. 1c).

\section{Response to $\mathrm{CoCl}_{2}$ treatment}

Hypoxic effects can be mimicked by the divalent transitionmetal ion cobalt. In the next experiments, differentiated human adipocytes (day 15 post-induction) were treated with $\mathrm{CoCl}_{2}$ at concentrations of 75 and $200 \mu \mathrm{M}$ for $24 \mathrm{~h} . \mathrm{CoCl}_{2}$ treatment resulted in a marked increase in total HIF- $1 \alpha$ protein, the level being fivefold higher at both doses compared to untreated cells (Fig. 2a). In contrast, HIF-1 $\alpha$ mRNA level was reduced three to fivefold by $\mathrm{CoCl}_{2}$ treatment (Fig. 2b).

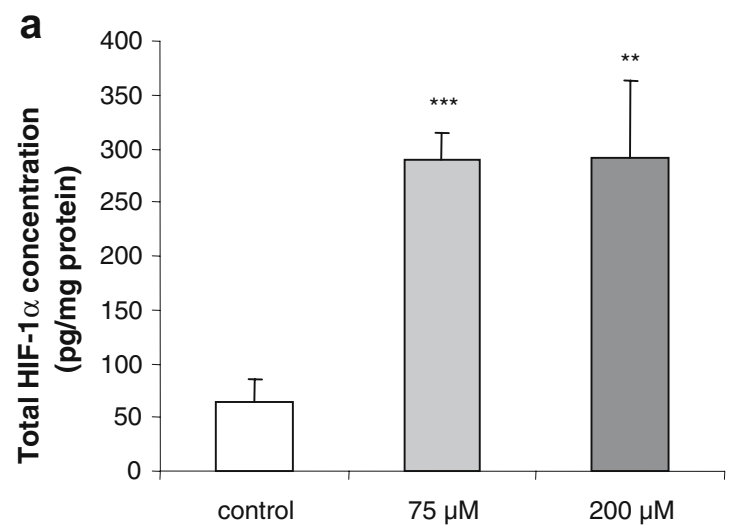

b

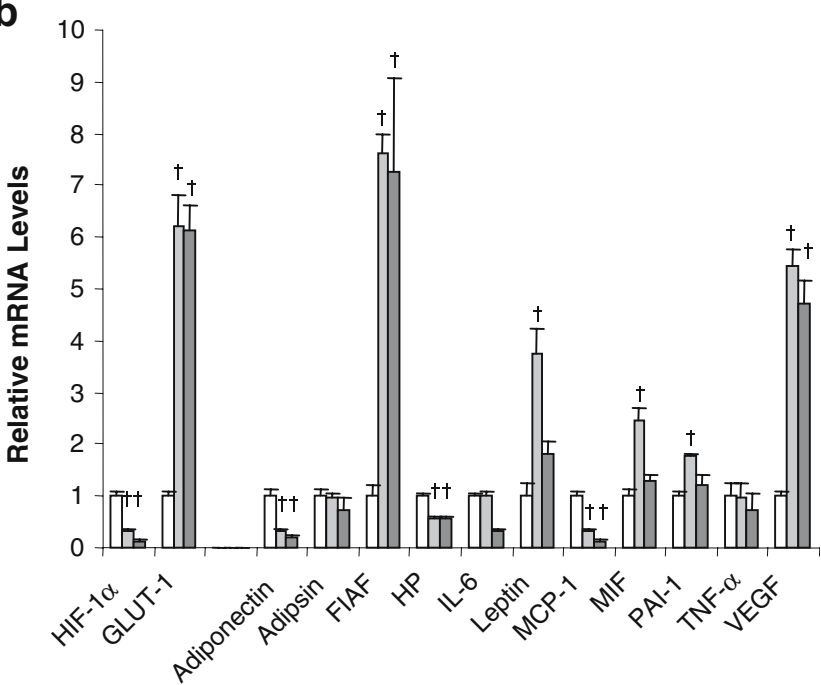

Fig. 2 Effect of $\mathrm{CoCl}_{2}$ at two dose levels on HIF-1 $\alpha$ protein concentration (a) and on the mRNA levels of HIF-1 $\alpha$, GLUT1 and adipokines (b) in human adipocytes. Differentiated human adipocytes at day 15 were incubated in medium containing 75 or $200 \mu \mathrm{M} \mathrm{CoCl}_{2}$ for $24 \mathrm{~h}$. Total HIF- $1 \alpha$ protein and mRNA level of adipokines were measured as described in Fig. 1. Results are means $\pm \operatorname{SE}(n=6)$. In a, ${ }^{* *} P<0.01, * * * P<0.001$ compared with controls; in $\mathbf{b} \dagger P<0.001$ compared with controls. Open bars, controls; shaded bars, 75 and $200 \mu \mathrm{m} \mathrm{CoCl}_{2}$ (light and dark bars, respectively) 
To assess whether human adipocytes respond to the $\mathrm{CoCl}_{2}$-induced increase in HIF-1 $\alpha$ protein by increasing the expression of 'classical' hypoxia-sensitive genes, the mRNA level of the GLUT1 facilitative glucose transporter was examined as a reference; this gene is recognised in other cells to be upregulated under hypoxic conditions. Treatment with $\mathrm{CoCl}_{2}$ induced a sixfold increase in GLUT1 mRNA level in the adipocytes (Fig. 2b).

The expression of a series of inflammation-related adipokine genes was then examined in the $\mathrm{CoCl}_{2}$-treated adipocytes, and three distinct responses were observed. No effect was found on TNF $\alpha$ or adipsin mRNA level at either of the two doses of $\mathrm{CoCl}_{2}$. There was, however, a significant reduction in mRNA level for adiponectin, MCP-1 and haptoglobin (Fig. 2b). Adiponectin mRNA level was decreased three to fourfold, MCP-1 by up to fivefold and haptoglobin mRNA by less than half with both concentrations. In the case of IL-6, the high dose of $\mathrm{CoCl}_{2}$ reduced mRNA level threefold, but there was no response with the lower dose (Fig. 2b). In contrast, $\mathrm{CoCl}_{2}$ treatment resulted in a marked increase in mRNA level for FIAF, leptin, MIF, PAI-1 and VEGF. The increase was six to sevenfold for VEGF and FIAF, and two to fourfold for PAI-1, MIF and leptin (Fig. 2b).

Time course of response to $\mathrm{CoCl}_{2}$

The previous experiment indicated that in most cases, there was little difference in the effect of 75 or $200 \mu \mathrm{M} \mathrm{CoCl}_{2}$ on HIF- $1 \alpha$ protein level and adipokine gene expression. However, with leptin, MIF and PAI-1 in particular, effects were noted with the lower, but not the higher, dose. This might suggest the possibility of additional, or toxic, responses to $\mathrm{CoCl}_{2}$ at higher doses. Consequently, in the subsequent time course study, a concentration of $100 \mu \mathrm{M}$ was employed at day 15 post-induction. There was a rapid and significant accumulation of HIF- $1 \alpha$ protein in human adipocytes after the addition of $\mathrm{CoCl}_{2}$. The protein level was increased 4.7 -fold by $2 \mathrm{~h}$ of $\mathrm{CoCl}_{2}$ treatment and peaked at $8 \mathrm{~h}$, at which point it was increased 7.7-fold before gradually falling (Fig. 3a). HIF-1 $\alpha$ protein level was also assessed by Western blotting, and the pattern of results was similar to that obtained by ELISA (Fig. 3b).

GLUT1 was again used as a hypoxia-sensitive reference gene, and the pattern of the time course of the changes in GLUT1 mRNA level was similar to that of HIF-1 $\alpha$ protein. The mRNA level was significantly increased (2.3-fold) by $2 \mathrm{~h}$, peaking at $8 \mathrm{~h}$, at which point it was 14-fold higher, gradually declining thereafter (Fig. 3c).

The time course of the effect of $\mathrm{CoCl}_{2}$ on the expression of genes encoding adipokines was next examined. A group of adipokines including FIAF, IL-6, leptin, MIF, PAI-1 and VEGF showed marked increases in mRNA level in

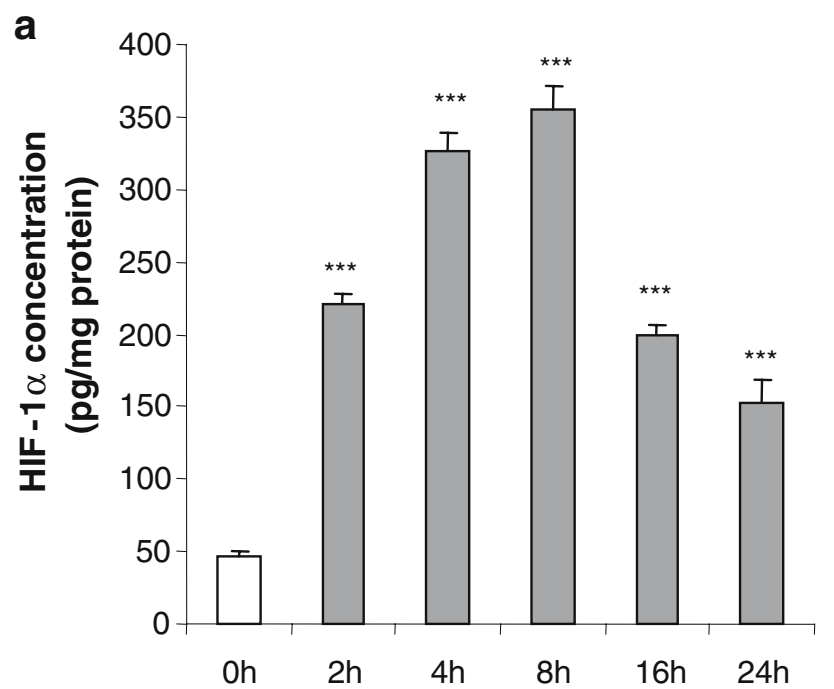

b
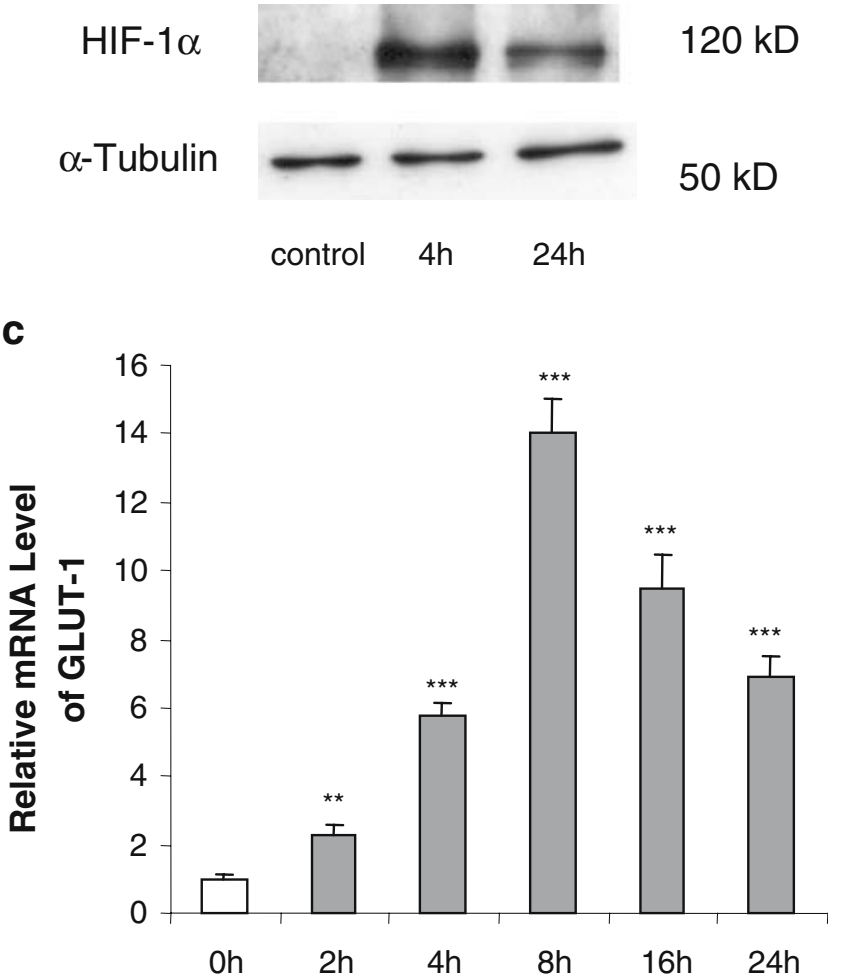

Fig. 3 Time course of effects of $\mathrm{CoCl}_{2}(100 \mu \mathrm{M})$ on total HIF-1 $\alpha$ protein level (a and b) and GLUT1 mRNA levels (c) in human adipocytes. Cells were cultured and treated as in Fig. 2. Results are means \pm SE $(n=4) .{ }^{* *} P<0.01, * * * P<0.001$ compared with 0 -h controls

response to $\mathrm{CoCl}_{2}$, some of which were both substantial and rapid. FIAF mRNA level was increased 30 -fold by $2 \mathrm{~h}$ after the addition of $\mathrm{CoCl}_{2}$, peaking at $8 \mathrm{~h}$, at which point it, had risen 210-fold (Fig. 4a). There was a fall thereafter, but even at $24 \mathrm{~h}$, FIAF mRNA was still elevated 30 -fold. A similar pattern was also evident with IL-6, PAI-1 and VEGF, but the changes were not as large (Fig. 4a). In comparison to the above genes, there was a more gradual 
Fig. 4 Time course of effects of $\mathrm{CoCl}_{2}(100 \mu \mathrm{M})$ on adipokine mRNA levels of FIAF, IL-6, leptin, MCP-1, MIF, PAI-1, TNF- $\alpha$ and VEGF (a) and adiponectin, haptoglobin and adip$\sin (\mathbf{b})$ in human adipocytes. Relative mRNA levels. Cells were cultured and treated as in Fig. 2. Results are means $\pm \mathrm{SE}$ $(n=4) . * P<0.05, * * P<0.01$, $* * * P<0.001$ compared with 0 -h controls
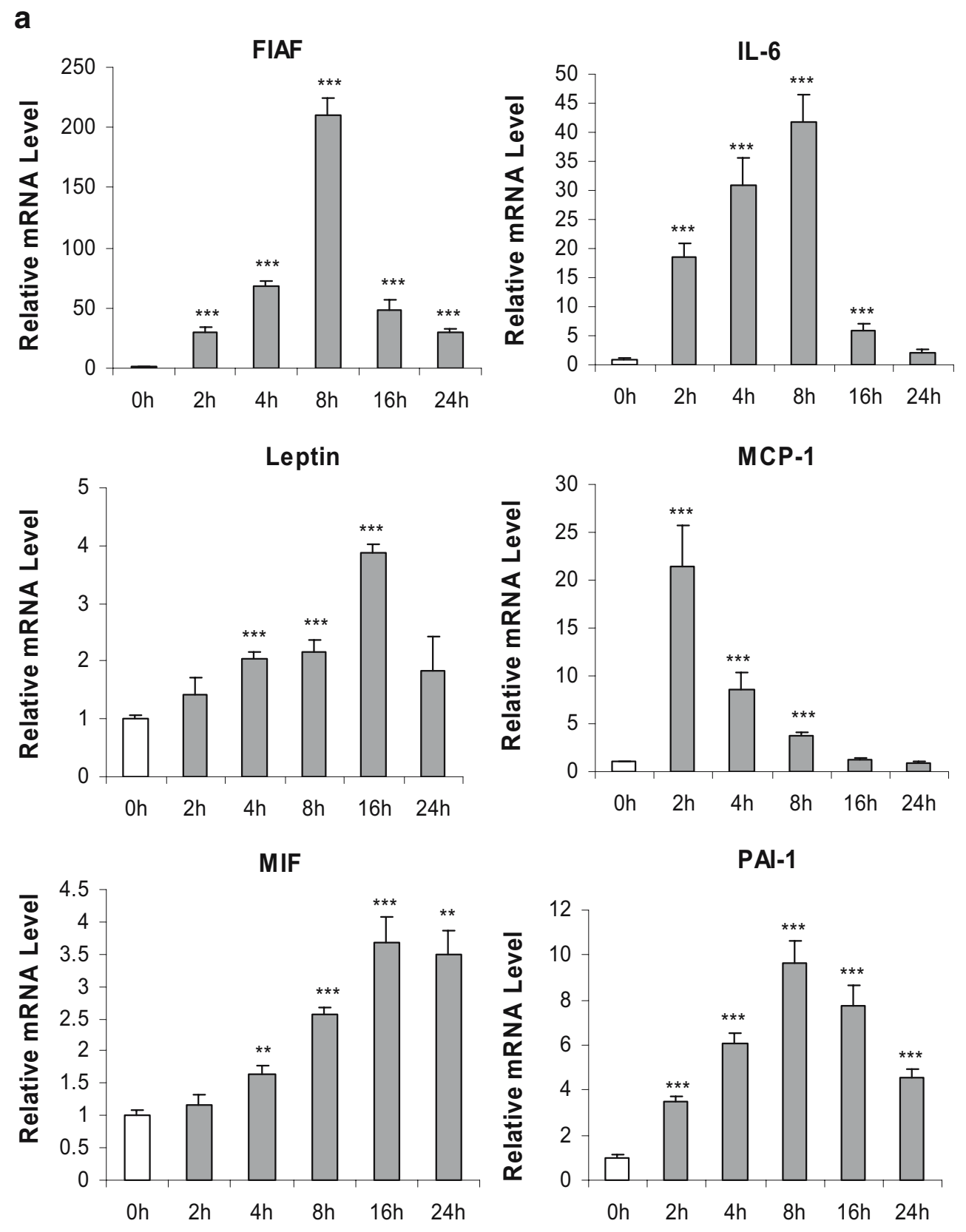

TNF- $\alpha$
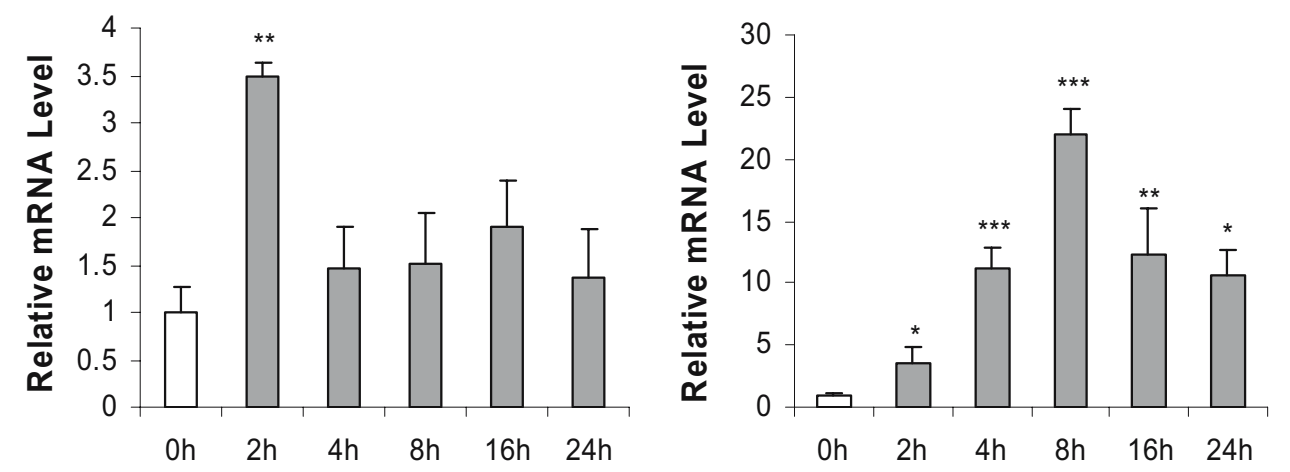
b
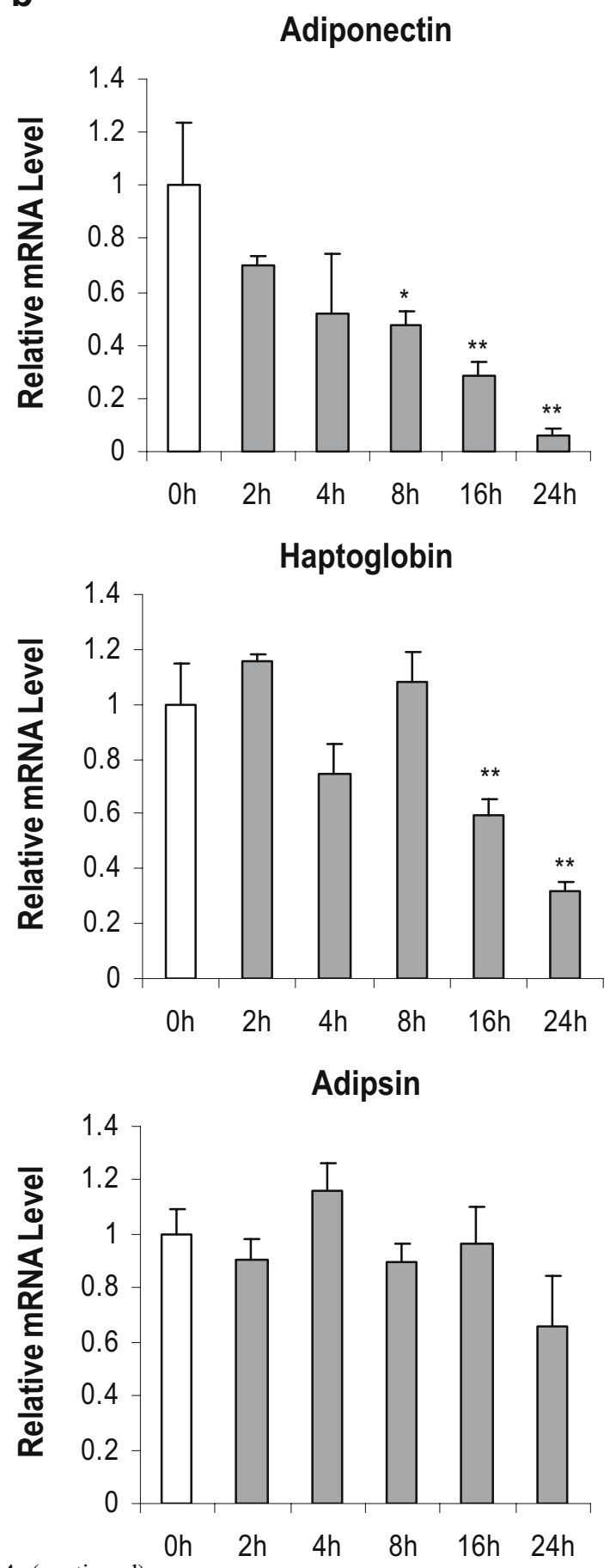

Fig. 4 (continued)

response to $\mathrm{CoCl}_{2}$ with leptin and MIF, the mRNA for each reaching a peak (fourfold) at $16 \mathrm{~h}$, with little change for the rest of the 24-h incubation period (Fig. 4a). Intriguingly, MCP-1 mRNA level exhibited a substantial acute increase, being elevated $>20$-fold at $2 \mathrm{~h}$, but there was a rapid decline thereafter such that at 16 and $24 \mathrm{~h}$ the levels were similar to the controls (Fig. 4a).
In contrast, to the genes described so far, no effect was found on mRNA level throughout the 24-h incubation period in the case of adipsin (Fig. 4b), while TNF $\alpha$ mRNA was also unchanged except for a transitory increase at $2 \mathrm{~h}$ only (Fig. 4a). There was, however, a significant reduction in mRNA level for adiponectin and haptoglobin after $8-16 \mathrm{~h}$ of the treatment; by $24 \mathrm{~h}$, adiponectin and haptoglobin mRNA was decreased by 15.7 -fold and threefold, respectively (Fig. 4).

Induction of HIF- $1 \alpha$ protein and GLUT1 gene expression by low $\mathrm{O}_{2}$ tension

In the next set of experiments, the direct effects of low $\mathrm{O}_{2}$ tension were examined. Human adipocytes at day 15 postdifferentiation were exposed to normoxic conditions $\left(21 \% \mathrm{O}_{2}\right)$ or to $1 \% \mathrm{O}_{2}$ for up to $24 \mathrm{~h}$. Some cells were returned to normoxia for $16 \mathrm{~h}$ after $8 \mathrm{~h}$ of exposure to $1 \% \mathrm{O}_{2}$ to examine the reversibility of responses. Total HIF-1 $\alpha$ protein level was measured by both ELISA and Western blotting. HIF- $1 \alpha$ concentration in cells was rapidly and substantially upregulated on exposure to $1 \% \mathrm{O}_{2}$, being 7.8 -fold higher by $4 \mathrm{~h}$ than in control cells cultured under normoxia. The HIF- $1 \alpha$ level fell markedly after $8 \mathrm{~h}$, but at $24 \mathrm{~h}$, it was still 3.8 -fold higher than in control cells (Fig. 5a). The transfer of adipocytes back to normoxic conditions after $8 \mathrm{~h}$ at $1 \% \mathrm{O}_{2}$ led to a rapid fall in HIF-1 $\alpha$, the level of the protein at $1 \mathrm{~h}$ being threefold lower than in cells maintained in $21 \% \mathrm{O}_{2}$ throughout (the cells were returned to normoxia after $8 \mathrm{~h}$, rather than $24 \mathrm{~h}$, because the high level of HIF-1 $\alpha$ at the earlier time point facilitated assessment of changes with normoxia). By $16 \mathrm{~h}$ after the return to normoxia, the level of HIF-1 $\alpha$ was similar to that in the control adipocytes. The pattern of HIF-1 $\alpha$ level as determined by ELISA was mirrored by Western blot analysis (Fig. 5b).

GLUT1 mRNA level was markedly increased (fivefold) after $4 \mathrm{~h}$ of exposure to $1 \% \mathrm{O}_{2}$ (Fig. $5 \mathrm{c}$ ) and reached a peak at $24 \mathrm{~h}$, being 14-fold higher than in cells maintained under normoxia. After exposure to hypoxia for $8 \mathrm{~h}$, the level of GLUT1 mRNA returned to normal after $16 \mathrm{~h}$ in $21 \% \mathrm{O}_{2}$ (Fig. 5c).

Regulation of adipokine gene expression by low $\mathrm{O}_{2}$ tension

The effect of hypoxia on the expression of genes encoding key inflammation-related adipokines was next examined. The first group of adipokines, which encompassed FIAF, IL-6, leptin, MIF, PAI-1 and VEGF, exhibited rapid and marked increases in mRNA level in response to hypoxia, as with $\mathrm{CoCl}_{2}$ treatment. FIAF mRNA level was increased 3.3 -fold by $4 \mathrm{~h}$ after exposure to $1 \% \mathrm{O}_{2}$, rising to 11 -fold by $24 \mathrm{~h}$ (Fig. 6a). FIAF mRNA level was completely normalised by $16 \mathrm{~h}$ of reexposure to normoxia after $8 \mathrm{~h}$ in 
a

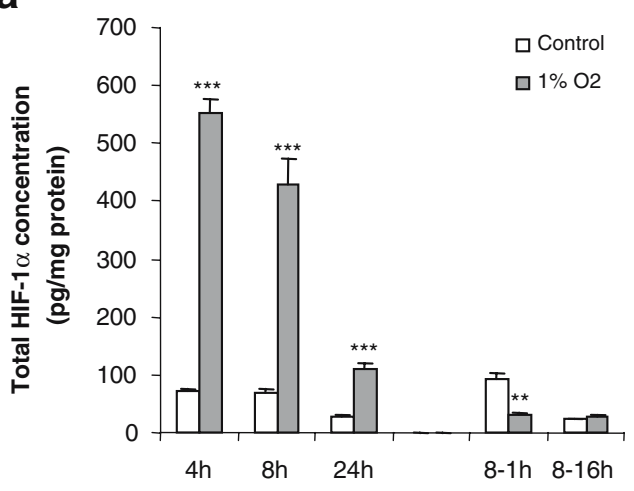

b
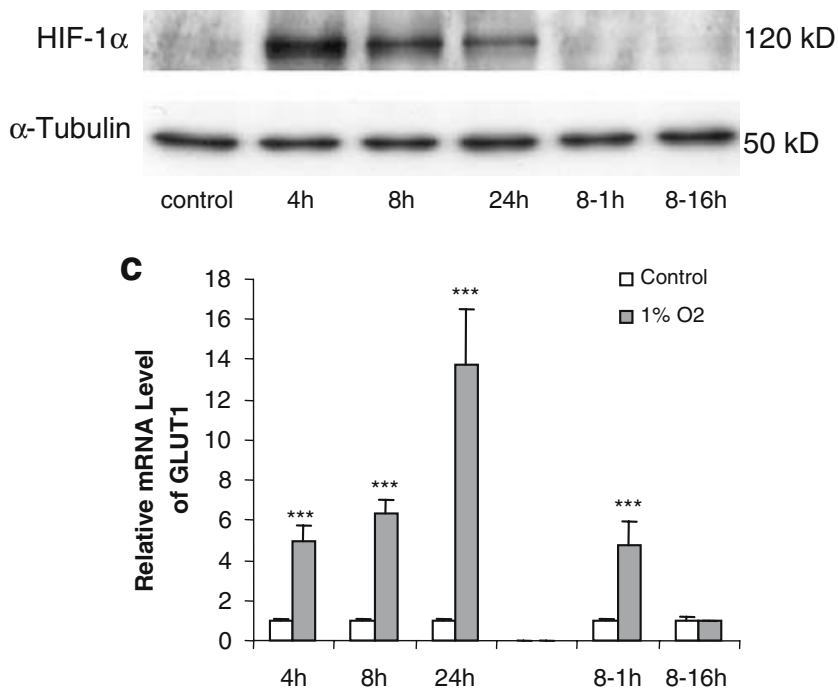

Fig. 5 Time course of effects of hypoxia $\left(1 \% \mathrm{O}_{2}\right)$ on total HIF- $1 \alpha$ protein level (a, b) and GLUT1 mRNA (c) levels in human adipocytes. Differentiated adipocytes at day 15 post-induction were exposed to $1 \% \mathrm{O}_{2}$ for up to $24 \mathrm{~h}$; some cells were transferred back to normoxic conditions $\left(21 \% \mathrm{O}_{2}\right)$ for 1 or $16 \mathrm{~h}$ after $8 \mathrm{~h}$ of hypoxia (8- to 1 - and 8- to 16-h groups). Results are means \pm SE $(n=4)$. ${ }^{*} P<0.05$, $* * P<0.01,{ }^{* * *} P<0.001$ compared with controls

$1 \% \mathrm{O}_{2}$. A similar pattern was also evident with five other adipokines. The changes were even more substantial in the case of leptin and VEGF. After $4 \mathrm{~h}$ of hypoxia, leptin and VEGF mRNA levels were increased four to fivefold and rose such that at $24 \mathrm{~h}$ they were 29 -fold and 23 -fold greater than in controls, respectively (Fig. 6a). Again, after $16 \mathrm{~h}$ of reexposure to normoxia after $8 \mathrm{~h}$ in $1 \% \mathrm{O}_{2}$, the mRNA level of these two adipokines had returned to normal.

IL-6, MIF and PAI-1 mRNA levels also showed significant increases in response to hypoxia, but these increases (2.5-fold to fivefold at $24 \mathrm{~h}$ ), were less than those exhibited by FIAF, leptin and VEGF. Returning the adipocytes to $21 \% \mathrm{O}_{2}$ led to a reversal by $16 \mathrm{~h}$ of the hypoxia-induced increases in IL-6, MIF and PAI-1 mRNA levels; in the case of IL-6, the mRNA was lower than in control cells at $16 \mathrm{~h}$ after the transfer from hypoxic to normoxic conditions.
In contrast to the genes described so far, there was a significant reduction in adiponectin and haptoglobin mRNA levels by the end of the 24-h exposure period, the decrease being two to threefold (Fig. 6b). This reduction was reversed after $1 \mathrm{~h}$ of reexposure to $21 \% \mathrm{O}_{2}$, but surprisingly was evident again after $16 \mathrm{~h}$ of reexposure. Adipsin mRNA level showed a significant, but very small, increase at 8 and $16 \mathrm{~h}$ (1.5 and 1.7-fold, respectively). There were no significant changes in the level of TNF $\alpha$ mRNA during exposure to $1 \% \mathrm{O}_{2}$, while MCP-1 mRNA was also unchanged after 4 and $24 \mathrm{~h}$ of hypoxia. For reasons that are not apparent, there was a significant reduction in MCP-1 mRNA at $8 \mathrm{~h}$, and this was sustained $1 \mathrm{~h}$ after return to normoxia (Fig. 6b).

\section{Adipokine secretion in hypoxia}

The secretion into the medium of a selected group of adipokines was examined during the exposure to hypoxia using specific ELISAs. A small but statistically significant reduction in adiponectin secretion was observed after 8 and $24 \mathrm{~h}$ incubation under $1 \% \mathrm{O}_{2}$ (Fig. 7a). This reduction was not evident after reexposure to $21 \% \mathrm{O}_{2}$ for $16 \mathrm{~h}$ (Fig. $7 \mathrm{a}$ ).

In marked contrast to adiponectin, there was a significant increase in leptin, MIF and VEGF release after both 8 and $24 \mathrm{~h}$ exposure to hypoxia (Fig. 7c-e). The increases in secretion were modest for MIF, but substantial in the case of both leptin and VEGF. Thus, after $24 \mathrm{~h}$ of hypoxia, leptin release was tenfold higher, while that of VEGF was fourfold greater. Elevated rates of secretion were still evident after transfer of the adipocytes from hypoxic to normoxic conditions, indicating a long-term carryover effect of low $\mathrm{O}_{2}$ tension. The secretion of IL-6 was not altered after $8 \mathrm{~h}$ of exposure to hypoxia, but it was significantly increased at $24 \mathrm{~h}$ (Fig. 7).

\section{Discussion}

An important recent development in our understanding of obesity is the emergence of the concept that it is characterised by a state of chronic low-grade inflammation $[7,9,38]$. White adipose tissue produces a number of adipokines linked to inflammation, including adiponectin, IL-1 $\beta$, IL-6, TNF $\alpha$, MCP-1 and MIF [11, 14, 26, 38], and their synthesis is generally substantially increased in obesity - with the exception of adiponectin whose production and circulating levels fall $[15,45]$. We have recently proposed that hypoxia may occur in adipocytes distant from the vasculature as adipose tissue mass expands and that this underlies the inflammatory response exhibited by the tissue [38]. The central aim of the present study was to examine 
Fig. 6 Time course of effects of hypoxia $\left(1 \% \mathrm{O}_{2}\right)$ on adipokine gene expression in human adipocytes.Relative mRNA levels of FIAF, IL-6, leptin, MIF, PAI$1, \operatorname{VEGF}$ (a) and adiponectin, haptoglobin, MCP-1, adipsin,

TNF- $\alpha$ (b). Cells were cultured as in Fig. 5; some cells were transferred back to normoxic conditions $\left(21 \% \mathrm{O}_{2}\right)$ for 1 or $16 \mathrm{~h}$ after $8 \mathrm{~h}$ of hypoxia (8- to 1 - and 8- to 16-h groups). Results are means \pm SE $(n=4)$. $* P<0.05, * * P<0.01, * * * P<$ 0.001 compared with controls a
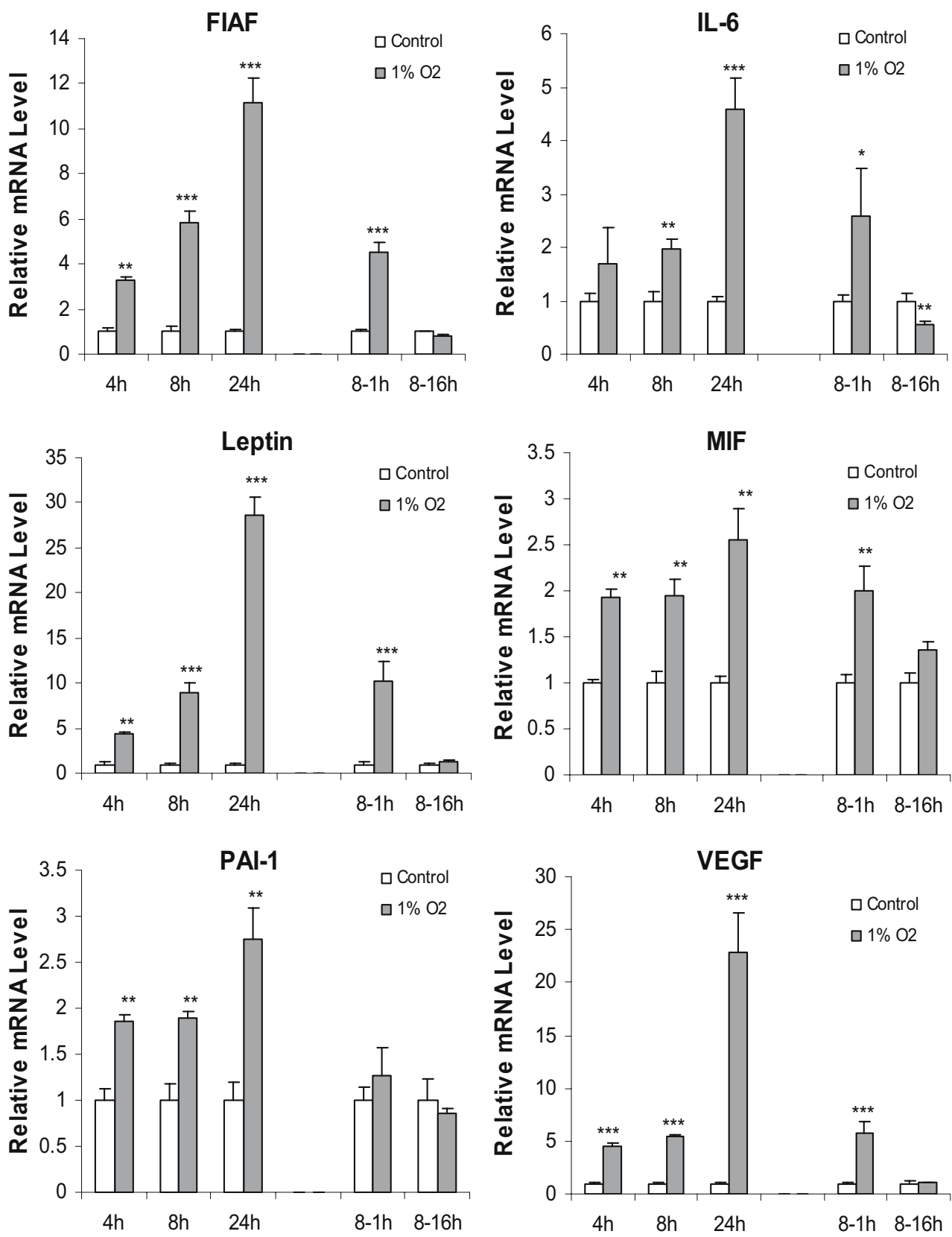

the effects of hypoxia on the expression and secretion of key inflammation-related adipokines in human adipocytes.

The transcription factor HIF-1 is a key signal in the cellular response to hypoxia, the $\alpha$-subunit of which is highly induced by hypoxia [13, 32, 44]. HIF-1 $\alpha$ expression was evident in human adipocytes, as noted previously in murine fat cells, and the level of both the mRNA and the protein fell after the induction of differentiation. It has been reported previously that HIF-1 $\alpha$ mRNA level in 3T3-L1 cells peaked at $3 \mathrm{~h}$ after the addition of induction medium and then rapidly decreased [16]. Immunoreactive HIF-1 $\alpha$ has been reported in murine adipocytes, and hypoxia results in an increase in the amount of the protein in cultured fat cells $[4,21]$. We have observed that the HIF-1 $\alpha$ gene is expressed in human, mouse and rat WAT depots, and expression occurs in both the mature adipocytes and in the cells of the stromal vascular fraction. A previous study has suggested that HIF-1 $\alpha$ is predominantly expressed in the stromal vascular fraction of obese subjects [3].

Hypoxia stabilises HIF-1 $\alpha$ protein, which is otherwise (under normoxic conditions) degraded by an ubiquitindependent proteasome [32]. Total HIF-1 $\alpha$ protein level in human adipocytes increased rapidly and substantially under hypoxic condition, both with $1 \% \mathrm{O}_{2}$ and by treatment with 
Fig. 6 (continued)

b
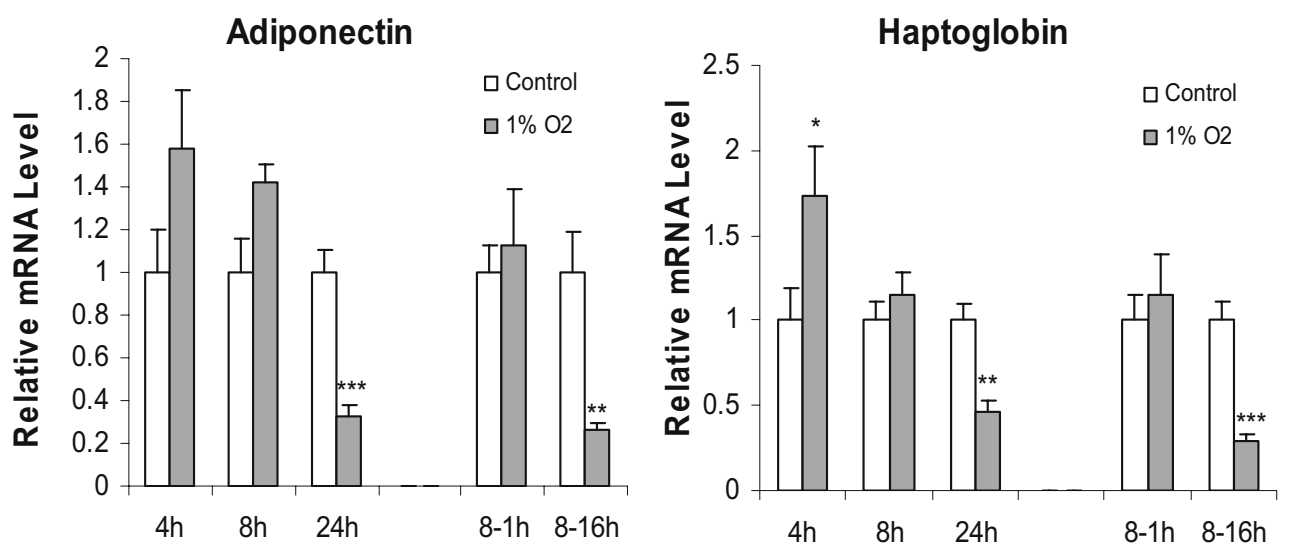
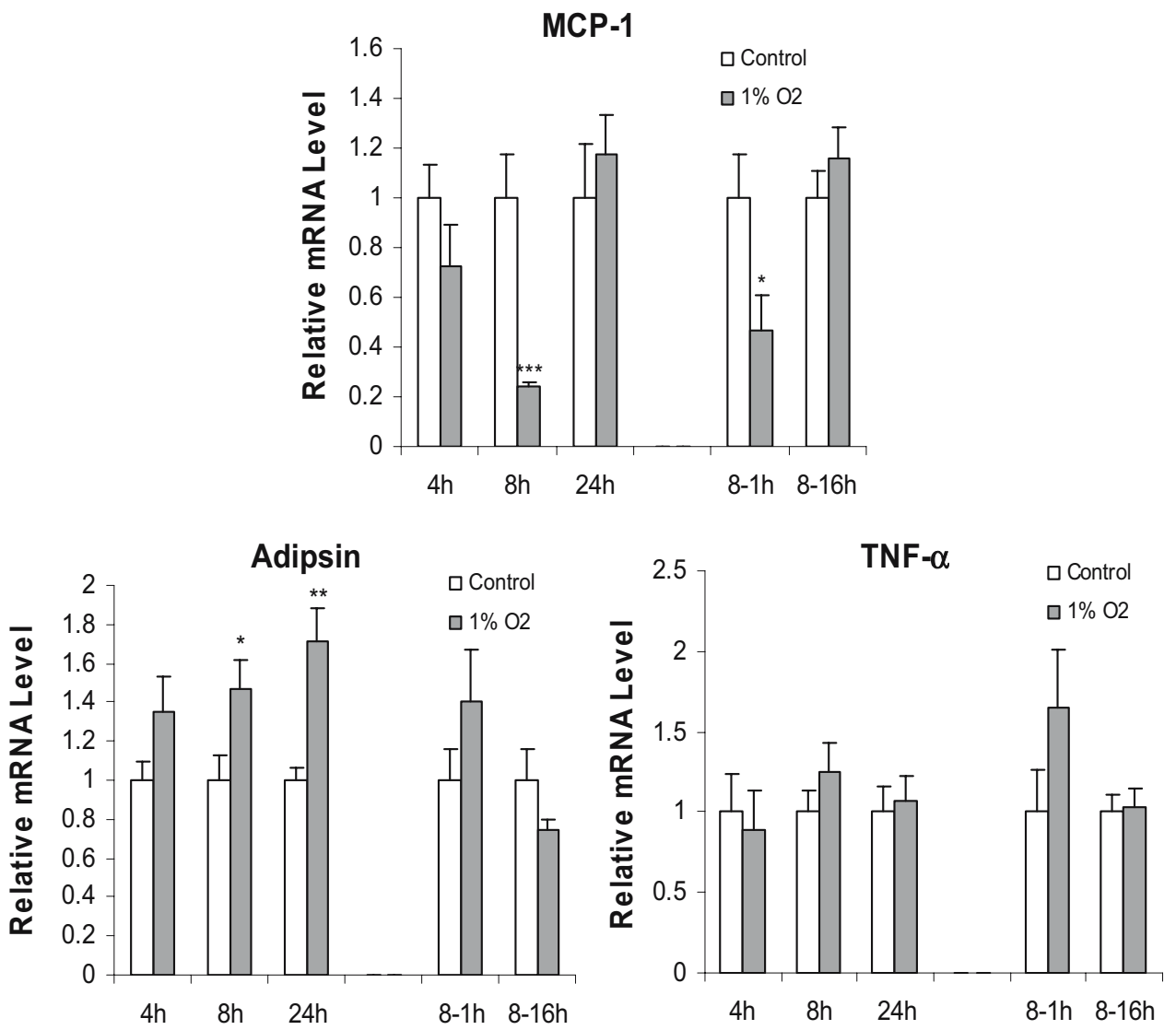

$\mathrm{CoCl}_{2}$. The elevated HIF- $1 \alpha$ protein rapidly fell on return to $21 \% \mathrm{O}_{2}$, and the level was even decreased compared to controls after $1 \mathrm{~h}$ of reoxygenation. Thus, the accumulated HIF- $1 \alpha$ in human adipocytes is rapidly degraded on returning to normoxia. Indeed, it was observed in another human adipocyte system (SGBS cells) that HIF-1 $\alpha$ protein declined to control levels by just 10 min after return to $21 \%$ $\mathrm{O}_{2}$ (Wang, unpublished results).

$\mathrm{CoCl}_{2}$, a known inducer of HIF- $1 \alpha$, has been widely employed as a hypoxia mimic and was used here to examine the effects of chemically induced hypoxia on adipokine gene expression. Previous studies have shown that at a global gene expression level, both $\mathrm{CoCl}_{2}$ and ambient hypoxia regulate a similar group of genes, and the observed similarity in gene expression appears to be dependent on functional HIF- $1 \alpha$ [40]. $\mathrm{CoCl}_{2}$ stabilises HIF-1 $\alpha$ under normoxia via inhibition of the iron-containing HIF prolyl hydroxylase enzyme, which plays a critical role in mediating normal hypoxic signalling by modifying HIF- $1 \alpha$ and targeting it for degradation.

Our results demonstrate that $\mathrm{CoCl}_{2}$ rapidly induces an accumulation of HIF-1 $\alpha$ and influences the expression of 
Fig. 7 Time course of effects of hypoxia $\left(1 \% \mathrm{O}_{2}\right)$ on the release of adipokines from human adipocytes. Adiponectin secretion (a) and IL6, leptin, MIF and VEGF release (b-e) after exposure to hypoxia. Adipokine concentration was measured by ELISA in the medium of cells cultured as in Fig. 6; some cells were transferred back to normoxic conditions $\left(21 \% \mathrm{O}_{2}\right)$ after $8 \mathrm{~h}$ of hypoxia and the adipokine concentration then measured $16 \mathrm{~h}$ later (8- to 16 -h group). Values are means \pm SE $(n=6) .{ }^{*} P<0.05, * * P<0.01, * * * P<0.001$ compared with controls

key inflammation-related adipokines in human adipocytes. Other studies have also found that $\mathrm{CoCl}_{2}(100 \mu \mathrm{M})$ causes HIF- $1 \alpha$ accumulation in various cell types, including bone marrow stromal cells, cancer cells and brown adipocytes $[20,24,27]$. In contrast to protein levels, HIF-1 $\alpha$ mRNA level was inhibited by $\mathrm{CoCl}_{2}$ treatment. This indicates that $\mathrm{CoCl}_{2}$ modulates HIF- $1 \alpha$ at the posttranslational rather than the transcriptional level. There is, however, evidence for hypoxic induction of HIF-1 $\alpha$ mRNA in some cells [17, 43].

Under hypoxia, GLUT1 gene expression has been shown to increase in several cell types, including rat liver cell lines and fibroblasts $[1,5]$, Chinese hamster ovary cells [48] and in human cancer cells [12]. Our data demonstrate that GLUT1 expression is also substantially upregulated by hypoxic conditions in human adipocytes. Measurement by Western blotting (using a specific antibody) of GLUT1 in total tissue lysates of adipocytes exposed to $1 \% \mathrm{O}_{2}$ demonstrated that the level of the protein was also increased by hypoxia; at $24 \mathrm{~h}$, GLUT1 protein was eightfold higher than in the normoxic controls (Wood, unpublished results). This phenomenon presumably reflects an adaptation of glucose metabolism to hypoxic conditions, with a marked stimulation of glycolysis in the face of a fall in aerobic metabolism.

During the adaptive response to hypoxia, the expression of several genes encoding glycolytic enzymes is recognised to increase [34]. To sustain higher levels of glycolysis, there is a need for an increase in glucose uptake, and this would be aided by an increase in the level of GLUT1 expression in hypoxia. GLUT1 is a key facilitative glucose transporter in white adipocytes, but other transporter isoforms such as GLUT4, GLUT8, GLUT10 and GLUT12 are also expressed in the cells $[46,47]$.

The main focus of the present study was the effects of hypoxia on the expression and secretion of adipokines, and qualitatively similar results were obtained over the same time scale with both $1 \% \mathrm{O}_{2}$ and $\mathrm{CoCl}_{2}$ treatment. Given the mechanism of action of $\mathrm{CoCl}_{2}$, this is consistent with the effects of hypoxia on adipokine production being mediated by HIF-1. Of the adipokines studied, the expression of TNF $\alpha$ and adipsin were not altered, and these genes would seem not to be hypoxia-sensitive. However, the expression of both adiponectin and haptoglobin (an acute phase protein) in human adipocytes was reduced by hypoxic conditions, and in the case of adiponectin, this was also $a$
$\overline{\bar{\varepsilon}}$
$\overline{0}$
0
0
0
0
$\frac{0}{0}$
0
0
$\frac{5}{0}$
0
0
0

b
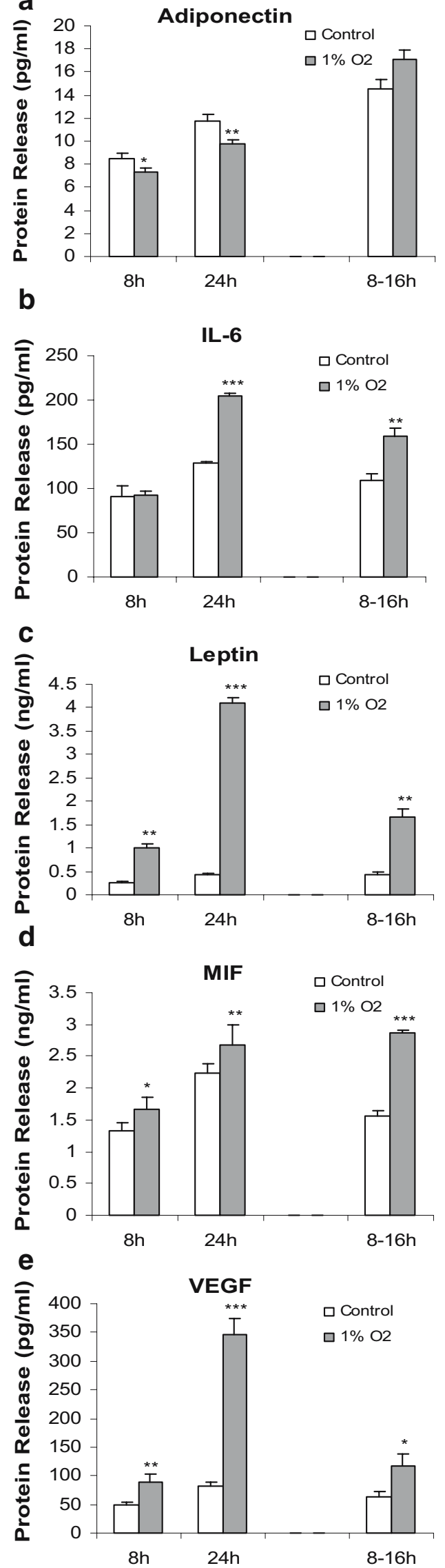
evident at the level of the secretion of the protein into the medium. The reduction, albeit modest, in adiponectin production in human adipocytes by hypoxia is consistent with a recent report in murine 3T3-L1 adipocytes [4]. There was a discrepancy in the present study between the changes in the scale of alterations in adiponectin mRNA level and the amount of adiponectin secreted into the medium. This may, however, reflect the lag between changes in mRNA and alterations in secreted protein.

In marked contrast to adiponectin, hypoxia stimulated the expression of the genes encoding FIAF, IL-6, leptin, MIF, PAI-1 and VEGF. VEGF is involved in the development of the vascular system, promoting angiogenesis, and is well known to be activated by hypoxia [50]. In the present study, an increase in VEGF protein secretion, as well as mRNA level, was observed in human adipocytes with hypoxia. This is in agreement with studies on rat omental adipose tissue and on murine 3T3-F442A adipocytes [21, 51].

Leptin is the most extensively studied adipokine, and adipose tissue is quantitatively the main leptin-producing organ. Activation of leptin gene expression by hypoxia resulted in a substantial increase in leptin release by human adipocytes. This would be expected to reduce food intake and stimulate energy expenditure, and as such, hypoxia could provide a mechanistic basis for the increase in leptin as adipose tissue mass expands in obesity. Leptin has been reported to be an angiogenic factor [35], and the physiological significance of a hypoxia-mediated induction of leptin secretion by adipocytes may relate to a local effect to stimulate the development of new blood vessels during adipose tissue expansion. Therefore, increased leptin production, together with that of VEGF, under hypoxic conditions could also reflect an adaptive process to promote angiogenesis, allowing appropriate oxygenation of adipose tissue. It has been previously established that leptin is a hypoxia-inducible hormone, and its production is increased by hypoxia in tissues such as the placenta, cardiac myocytes and cancer cells $[8,10,23]$ as well as in murine 3T3-F442A adipocytes [21].

FIAF (also known as angiopoietin-like protein 4) is expressed particularly in adipose tissue and the liver, and has been suggested to play a role in adipose differentiation, systemic lipid metabolism and energy homeostasis [18]. In parallel with the activation of leptin and VEGF, FIAF expression was highly activated by hypoxia in human adipocytes; FIAF expression has also been shown to be hypoxia-sensitive in cardiomyocytes through a HIF-1dependent pathway [2]. The major upregulation of FIAF by hypoxia in adipocytes may again relate to angiogenesis, this being one of the functions suggested for this protein [22]. However, a major effect of FIAF is in the clearance of plasma triglycerides through an inhibition of lipoprotein lipase, and it also appears to stimulate lipolysis [18]. Thus, the hypoxia-induced stimulation of FIAF production may alter lipid utilisation.

The present study shows that the expression and release of MIF, a potent macrophage migration inhibitory factor which has recently been shown to be secreted from human adipocytes [36], was also stimulated by hypoxia. MIF has been described as a pro-inflammatory agent, and elevated expression has been seen in many inflammatory pathologies. Although MIF may play a role in the normal adaptive response to hypoxia, it is likely that exaggerated expression of MIF may contribute to the inflammatory state. It has also been proposed that MIF may play an important role in oncogenic transformation and tumour survival, and recent studies have implicated MIF in the regulation of VEGF expression [28]. In this context, during hypoxia, elevated MIF expression may play an important role in enhancing angiogenesis as well as macrophage recruitment. In contrast to MIF, no consistent pattern was observed with MCP-1, an important factor in macrophage recruitment; the acute, but transitory, increase in MCP-1 mRNA observed with $\mathrm{CoCl}_{2}$ may reflect an effect of the metal unrelated to hypoxia.

The expression and release of the classic inflammatory factor IL-6 was significantly upregulated by hypoxia. Thus, hypoxia can directly affect key components of the inflammatory cascade within adipose tissue. The expression of PAI-1, an acute phase protein involved in fibrinolysis, was modestly increased in human adipocytes by hypoxia, consistent with the effects observed in 3T3-L1 adipocytes [4]. Induction of PAI-1 expression by hypoxia has also been reported in HepG2 cells [19] and in vascular smooth muscle cells [30].

Overall, the present results indicate that a number of genes are hypoxia-sensitive in human adipocytes and suggest that HIF-1 is involved in the transmission of the response to low $\mathrm{O}_{2}$ tension in these, as in other, cell types. The hypoxia-sensitive genes in adipocytes include those involved in basic metabolic processes, such as glucose transport, as well as those linked to energy balance, inflammation and angiogenesis. The stimulation of IL-6, leptin, MIF, PAI-1 and VEGF expression, together with the downregulation of adiponectin synthesis, is consistent with our recent proposal that hypoxia may underlie the inflammatory response in adipose tissue in obesity and play a causal role in the development of obesity-associated diseases [38]. There was, however, no effect of hypoxia on the expression of $\mathrm{TNF} \alpha$, a key pro-inflammatory cytokine. The hypoxia-induced changes in IL-6 and adiponectin, with its anti-inflammatory action, in particular, might be expected to impact on insulin sensitivity.

Acknowledgements We are grateful to Dr. Aphrodite Vasilaki and Professor Malcolm Jackson for providing access to the hypoxic chamber and to Mr. Leif Hunter for his help. We also gratefully acknowledge the receipt of funding from the BBSRC (UK). 


\section{References}

1. Behrooz A, Ismail-Beigi F (1997) Dual control of GLUT1 glucose transporter gene expression by hypoxia and by inhibition of oxidative phosphorylation. J Biol Chem 272:5555-5562

2. Belanger AJ, Lu H, Date T, Liu LX, Vincent KA, Akita GY, Cheng SH, Gregory RJ, Jiang C (2002) Hypoxia up-regulates expression of peroxisome proliferator-activated receptor gamma angiopoietin-related gene (PGAR) in cardiomyocytes: role of hypoxia inducible factor $1 \alpha$. J Mol Cell Cardiol 34:765-774

3. Cancello R, Henegar C, Viguerie N, Taleb S, Poitou C, Rouault C, Coupaye M, Pelloux V, Hugol D, Bouillot J-L, Bouloumie A, Barbatelli G, Cinti S, Svensson P-A, Barsh GS, Zucker J-D, Basdevant A, Langin D, Clément K (2005) Reduction of macrophage infiltration and chemoattractant gene expression changes in white adipose tissue of morbidly obese subjects after surgery-induced weight loss. Diabetes 54:2277-2286

4. Chen B, Lam KSL, Wang Y, Wu D, Lam MC, Shen J, Wong L, Hoo RLC, Zhang J, Xu A (2006) Hypoxia dysregulates the production of adiponectin and plasminogen activator inhibitor-1 independent of reactive oxygen species in adipocytes. Biochem Biophys Res Commun 341:549-556

5. Chen C, Pore N, Behrooz A, Ismail-Beigi F, Maity A (2001) Regulation of GLUT1 mRNA by hypoxia-inducible factor-1. Interaction between H-ras and hypoxia. J Biol Chem 276:9519-9525

6. Cummins EP, Taylor CT (2005) Hypoxia-responsive transcription factors. Pflügers Arch Eur J Physiol 450:363-371

7. Engström G, Hedblad B, Stavenow L, Lind P, Janzon L, Lindgärde F (2003) Inflammation-sensitive plasma proteins are associated with future weight gain. Diabetes 52:2097-2101

8. Erkasap N, Ikizler M, Shneyvays V, Zinman T, Mamedova LK, Uyar R, Shainberg A (2006) Leptin protects the cardiac myocyte cultures from hypoxic damage. Life Sci 78:1098-1102

9. Fasshauer M, Paschke R (2003) Regulation of adipocytokines and insulin resistance. Diabetologia 46:1594-1603

10. Garofalo C, Koda M, Cascio S, Sulkowska M, Kanczuga-Koda L, Golaszewska J, Russo A, Sulkowski S, Surmacz E (2006) Increased expression of leptin and the leptin receptor as a marker of breast cancer progression: possible role of obesity-related stimuli. Clin Cancer Res 12:1447-1453

11. Hauner H (2005) Secretory factors from human adipose tissue and their functional role. Proc Nutr Soc 64:163-169

12. Hayashi M, Sakata M, Takeda T, Yamamoto T, Okamoto Y, Sawada K, Kimura A, Minekawa R, Tahara M, Tasaka K, Murata $Y$ (2004) Induction of glucose transporter 1 expression through hypoxia-inducible factor $1 \alpha$ under hypoxic conditions in trophoblast-derived cells. J Endocrinol 183:145-154

13. Hopfl G, Ogunshola O, Gassmann M (2004) HIFs and tumorscauses and consequences. Am J Physiol Regul Integr Comp Physiol 286:R608-R623

14. Hotamisligil GS (2006) Inflammation and metabolic disorders. Nature 444:860-867

15. Hu E, Liang P, Spiegelman BM (1996) AdipoQ is a novel adiposespecific gene dysregulated in obesity. J Biol Chem 271:10697-10703

16. Imagawa M, Tsuchiya $T$, Nishihara $T$ (1999) Identification of inducible genes at the early stage of adipocyte differentiation of 3T3-L1 cells. Biochem Biophys Res Commun 254:299-305

17. Jiang CQ, Fan LF, Liu ZS, Qian Q, Xia D, Diao LM, He YM, Ai ZL (2004) Expression levels and significance of hypoxia inducible factor- $1 \alpha$ and vascular endothelial growth factor in human colorectal adenocarcinoma. Chin Med J (Engl) 117:1541-1546

18. Kersten S (2005) Regulation of lipid metabolism via angiopoietinlike proteins. Biochem Soc Trans 33:1059-1062

19. Kietzmann T, Roth U, Jungermann K (1999) Induction of the plasminogen activator inhibitor-1 gene expression by mild hypoxia via a hypoxia response element binding the hypoxiainducible factor-1 in rat hepatocytes. Blood 94:4177-4185

20. Knowles HJ, Raval RR, Harris AL, Ratcliffe PJ (2003) Effect of ascorbate on the activity of hypoxia-inducible factor in cancer cells. Cancer Res 63:1764-1768

21. Lolmède K, Durand de Saint Front V, Galitzky J, Lafontan M, Bouloumie A (2003) Effects of hypoxia on the expression of proangiogenic factors in differentiated 3T3-F442A adipocytes. Int J Obes 27:1187-1195

22. Mandard S, Zandbergen F, Tan NS, Escher P, Patsouris D, Koenig W, Kleemann R, Bakker A, Veenman F, Wahli W, Muller M, Kersten S (2004) The direct peroxisome proliferator-activated receptor target fasting-induced adipose factor (FIAF/PGAR/ ANGPTL4) is present in blood plasma as a truncated protein that is increased by fenofibrate treatment. J Biol Chem 279:3441134420

23. Mise H, Sagawa N, Matsumoto T, Yura S, Nanno H, Itoh H, Mori T, Masuzaki H, Hosoda K, Ogawa Y, Nakao K (1998) Augmented placental production of leptin in preeclampsia: Possible involvement of placental hypoxia. J Clin Endocrinol Metab 83:3225-3229

24. Nikami H, Nedergaard J, Fredriksson JM (2005) Norepinephrine but not hypoxia stimulates HIF-1 $\alpha$ gene expression in brown adipocytes. Biochem Biophys Res Commun 337:121-126

25. Ouchi N, Kihara S, Arita Y, Okamoto Y, Maeda K, Kuriyama H, Hotta K, Nishida M, Takahashi M, Muraguchi M, Ohmoto Y, Nakamura T, Yamashita S, Funahashi T, Matsuzawa Y (2000) Adiponectin, an adipocyte-derived plasma protein, inhibits endothelial NF-kappa B signaling through a cAMP-dependent pathway. Circulation 102:1296-1301

26. Rajala MW, Scherer PE (2003) The adipocyte - at the crossroads of energy homeostasis, inflammation, and atherosclerosis. Endocrinology 144:3765-3773

27. Ren H, Cao Y, Zhao Q, Li J, Zhou C, Liao L, Jia M, Zhao Q, Cai H, Han ZC (2006) Proliferation and differentiation of bone marrow stromal cells under hypoxic conditions. Biochem Biophys Res Commun 347:12-21

28. Ren Y, Chan HM, Li Z, Lin C, Nicholls J, Chen CF, Lee PY, Lui V, Bacher M, Tam PK (2004) Upregulation of macrophage migration inhibitory factor contributes to induced N-Myc expression by the activation of ERK signaling pathway and increased expression of interleukin-8 and VEGF in neuroblastoma. Oncogene 23:4146-4154

29. Rosen ED, Spiegelman BM (2006) Adipocytes as regulators of energy balance and glucose homeostasis. Nature 444:847-853

30. Sato H, Sato M, Kanai H, Uchiyama T, Iso T, Ohyama Y, Sakamoto H, Tamura J, Nagai R, Kurabayashi M (2005) Mitochondrial reactive oxygen species and $\mathrm{c}$-Src play a critical role in hypoxic response in vascular smooth muscle cells. Cardiovasc Res 67:714-722

31. Segawa K, Fukuhara A, Hosogai N, Morita K, Okuno Y, Tanaka M, Nakagawa Y, Kihara S, Funahashi T, Komuro R (2006) Visfatin in adipocytes is upregulated by hypoxia through HIF $1 \alpha$-dependent mechanism. Biochem Biophys Res Commun 349:875-882

32. Semenza GL (2001) HIF-1 and mechanisms of hypoxia sensing. Curr Opin Cell Biol 13:167-171

33. Semenza GL (2003) Targeting HIF-1 for cancer therapy. Nat Rev Cancer 3:721-732

34. Semenza GL, Jiang BH, Leung SW, Passantino R, Concordet JP, Maire P, Giallongo A (1996) Hypoxia response elements in the aldolase A, enolase 1, and lactate dehydrogenase A gene promoters contain essential binding sites for hypoxia-inducible factor 1. J Biol Chem 271:32529-32537

35. Sierra-Honigmann MR, Nath AK, Murakami C, García-Cardeña G, Papapetropoulos A, Sessa WC, Madge LA, Schechner JS, Schwabb MB, Polverini PJ, Flores-Riveros JR (1998) Biological action of leptin as an angiogenic factor. Science 281:1683-1686 
36. Skurk T, Herder C, Kraft I, Muller-Scholze S, Hauner H, Kolb H (2005) Production and release of macrophage migration inhibitory factor from human adipocytes. Endocrinology 146:1006-1011

37. Trayhurn P, Beattie JH (2001) Physiological role of adipose tissue: white adipose tissue as an endocrine and secretory organ. Proc Nutr Soc 60:329-339

38. Trayhurn P, Wood IS (2004) Adipokines: inflammation and the pleiotropic role of white adipose tissue. Br J Nutr 92:347-355

39. Trayhurn P, Wood IS (2005) Signalling role of adipose tissue: adipokines and inflammation in obesity. Biochem Soc Trans 33:1078-1081

40. Vengellur A, Woods BG, Ryan HE, Johnson RS, LaPres JJ (2003) Gene expression profiling of the hypoxia signaling pathway in hypoxia-inducible factor $1 \alpha$ null mouse embryonic fibroblasts. Gene Expr 11:181-197

41. Wang B, Jenkins JR, Trayhurn P (2005) Expression and secretion of inflammation-related adipokines by human adipocytes differentiated in culture: integrated response to TNF- $\alpha$. Am J Physiol Endocrinol Metab 288:E731-E740

42. Wang B, Trayhurn P (2006) Acute and prolonged effects of TNFalpha on the expression and secretion of inflammation-related adipokines by human adipocytes differentiated in culture. Pflügers Archiv Eur J Physiol 452:418-427

43. Wang GL, Jiang BH, Rue EA, Semenza GL (1995) Hypoxia-inducible factor 1 is a basic-helix-loop-helix-PAS heterodimer regulated by cellular O2 tension. Proc Natl Acad Sci USA 92:5510-5514

44. Wenger RH (2002) Cellular adaptation to hypoxia: O2-sensing protein hydroxylases, hypoxia-inducible transcription factors, and O2-regulated gene expression. FASEB J 16:1151-1162
45. Weyer C, Funahashi T, Tanaka S, Hotta K, Matsuzawa Y, Pratley RE, Tataranni PA (2001) Hypoadiponectinemia in obesity and type 2 diabetes: close association with insulin resistance and hyperinsulinemia. J Clin Endocrinol Metab 86:1930-1935

46. Wood IS, Hunter L, Trayhurn P (2003) Expression of class III facilitative glucose transporter genes (GLUT-10 and GLUT-12) in mouse and human adipose tissues. Biochem Biophys Res Commun 308:43-49

47. Wood IS, Trayhurn P (2003) Glucose transporters (GLUT and SGLT): expanded families of sugar transport proteins. Br J Nutr 89:3-9

48. Wood SM, Wiesener MS, Yeates KM, Okada N, Pugh CW, Maxwell PH, Ratcliffe PJ (1998) Selection and analysis of a mutant cell line defective in the hypoxia-inducible factor-1 alphasubunit (HIF-1 $\alpha)$. Characterization of HIF- $1 \alpha$-dependent and independent hypoxia-inducible gene expression. J Biol Chem 273:8360-8368

49. Yokota T, Oritani K, Takahashi I, Ishikawa J, Matsuyama A, Ouchi N, Kihara S, Funahashi T, Tenner AJ, Tomiyama Y, Matsuzawa Y (2000) Adiponectin, a new member of the family of soluble defense collagens, negatively regulates the growth of myelomonocytic progenitors and the functions of macrophages. Blood 96:1723-1732

50. Zagorska A, Dulak J (2004) HIF-1: the knowns and unknowns of hypoxia sensing. Acta Biochim Pol 51:563-585

51. Zhang QX, Magovern CJ, Mack CA, Budenbender KT, Ko W, Rosengart TK (1997) Vascular endothelial growth factor is the major angiogenic factor in omentum: mechanism of the omentummediated angiogenesis. J Surg Res 67:147-154 